\title{
The Wealth Effects Of Managerial Turnover: Implications For The Spanish Corporate Governance System
}

\author{
Carlos Fernández Méndez, (E-mail: cfernan@correo.uniovi.es), University de Oviedo, Spain
}

\begin{abstract}
Managerial succession decisions constitute crucial events for the company, as they can generate important organizational changes that affect the shareholders' wealth, and at the same time, entail important conflicts of interests between the managers and the shareholders. Our study of the market reactions to managerial turnover announcements in the Spanish market, reveal that these decisions have a positive effect on the shareholders' wealth. These wealth effects are especially intense in the case of outsider successions and when the company preturnover performance has been poor. These findings suggest that managerial turnover is a restructuring decision that is most welcome under conditions of low performance. These results are reinforced by the existence of a negative relationship between the turnover wealth effects and the firm's preturnover performance. Our results also have implications regarding the effectiveness of the Spanish corporate governance system, suggesting that the Board's outsiders and the institutional shareholders play a major monitoring role in the managerial succession processes. The Board outsiders and the institutional shareholders influence the succession process protecting the shareholders' interests against particular professional interests of the managers. We have also found evidences of the existence of entrenchment effects linked to managerial stock ownership. Finally, consistently with our event study results, we have found evidences of a positive effect of outside succession on the market's reaction to managerial turnover, in the case of a poor presuccession performance context. We have obtained no evidence about any effect from outside succession in good performing companies or inside succession in any company independently of its previous performance.
\end{abstract}

\section{Introduction}

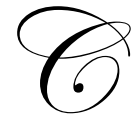

EO succession consequences on the shareholders' wealth and the implication of the Board of directors and other control mechanisms in this event is a major question in the corporate governance literature. In this study we analyse the wealth effects linked to managerial succession events and the implication of the corporate governance system in the outcomes of this event.

There is not a consensus about the effects of managerial turnover on firm's performance and the shareholders' wealth. There are marked differences in the way different authors see managerial turnover. Pfeffer and Salancik, (1978) consider managerial turnover as a mean to adapt the firm to the changing requirements of the environment. Managerial succession is an occasion to replace decision makers with others whose capabilities are more suitable to solve critical problems posed by the firm's environment. The better alignment between the firm and its environment has therefore a positive effect on the shareholders wealth. On the other hand, other authors consider managerial turnover as a disruptive event that brakes organisational routines, and therefore, affects negatively the firm's performance (Grusky, 1963). A third view considers that managerial succession has a negligible effect on firm's performance, as the firm's profitability is a function of organisational processes and external variables that are outside the control of the manager (Gamson and Scotch, 1964).

Readers with comments or questions are encouraged to contact the author via email. 
In an attempt to analyse the effects of managerial turnover decisions on organisational outcomes, we study the market's reaction to these events. Any significant reaction would imply that managerial turnover brings about a change in the estimated amount of cash flows generated in the future by the company. The market reactions will therefore inform us about the relevance of managerial turnover.

Given that managerial succession decisions are taken by the Board of Directors, the analysis of its derived market reactions can provide evidence on the control activity performed by the Board, and in general, by all the monitoring mechanisms that form the corporate governance system in the Spanish economy. The study of the supervisory activity in managerial turnover decisions is specially relevant, given that substituting a top manager is a source of interest conflicts between the managers and the shareholders. If the set of control mechanisms in place are acting in the shareholders' best interest, the proper successor will be selected, and turnover will bring an improvement in the suitability of the manager for the demands of his/her roles. In this way, the study of the relationship between the market reactions to managerial turnover and the different control mechanisms that can affect the succession decision, will show the intensity of shareholders' interest protection by the corporate governance system. Therefore this study tries to extend corporate governance research, mainly developed in the Anglo-Saxon economic context, to the Spanish economy, in which shareholders' interests protection is internally exerted by the Board of directors and the stock ownership concentration.

The remaining sections of this paper are organised as follows. Section two discusses the determinants of managerial turnover wealth effects and resumes the hypothesis of the study. Section three describes the variables and the models used to test these hypothesis. Section four describes the data set. Section five presents our main empirical results and section six concludes.

\section{Determinants Of The Market's Reaction To Managerial Succession}

The substitution and selection of new managers is a significant matter since the future outcomes of the firm, and therefore the shareholders' wealth, could greatly depend on the suitability of the succession decision. Under the "common-sense" theoretical point of view the manager has control on organisational outcomes. Thus, managerial turnover provides an opportunity to improve the leader's capabilities to run the firm. If chosen adequately, the new selected manager can avoid at least some of the mistakes made his/her predecessor, improving in this way the performance of the organisation. To the extent that the investor's community perceives this improvement in expected firm's cash flows after a managerial succession event, there will be a positive market reaction around managerial turnover announcement. Under this theoretical point of view, we expect that managerial turnover announcements will generate positive abnormal market returns.

Conducting the managerial succession process is one of the Board of Directors' duties. Managerial succession provides therefore evidence of whether the Board and alternative internal control mechanisms, that are prevalent in the Spanish governance system, are acting on the shareholders' best interest. If the managerial succession decisions taken by the Board of Directors are consistent with the shareholders' value maximization, the shareholders' wealth will increase after the turnover announcement. Although the Board is the last mechanism responsible for the succession decisions, the rest of control mechanisms in place can induce value enhancing Board's actions. Therefore, besides the Board's characteristics, other control mechanisms, in the Spanish case principally related to stock ownership structure, are going to determine the market's reaction to managerial succession.

\subsection{Firm's Preturnover Performance}

The firm's performance indicates, to a certain extent, the quality of managerial decisions. In that sense, when the firm is performing poorly it signs the need for a change in its strategies to recover profitability. On the contrary, when the firm profitability is high enough to fairly compensate the shareholders for their financing and risk bearing functions, there is an incentive for continuity and stability in the strategies and policies of the company.

Managerial succession brings about important organisational changes. Different authors have observed the existence of restructuring processes promoted by managerial succession. Weisbach (1995) found a higher probabil- 
ity of divesting non profitable acquisitions after managerial turnover. In line with this finding, Denis and Denis (1995) have found evidence that non routine managerial turnover is followed by a downsizing process affecting the firm's assets and labour force. The managerial turnover provides an opportunity to correct previous managerial non enhancing decisions. According to that, Denis and Denis (1995), Guest (1962) and Tushman and Rosenkopf (1996) found evidences of a positive effect on the firm's performance derived from managerial turnover.

If managerial turnover generates organisational changes, managerial succession is going to be better valued by the shareholders when organisational changes is necessary, that is when the firm's performance is low. Therefore, we propose the following hypothesis.

Turn around hypothesis: The lower the firm's preturnover performance the higher the stock market reaction to managerial succession.

\subsection{The effect of the governance structure on managerial turnover}

The effect of managerial turnover on the firm's performance depends not only on the suitability of removing the present manager, but on the selection of a successor that fits to the firm's needs. To this respect, the market reaction to managerial turnover depends on the confidence that the investors community has on the capability of the Board of directors to select a good successor. To the extent that the governance structure guarantees that the Board of directors is able to successfully represent the shareholders' interests, the Board's decisions, including managerial turnover, are going to be favourably assessed by the investors. In that sense, the presence of Board outsiders, the alignment effect linked to managerial stock ownership and the presence of large independent shareholders, favour the governance activity exerted by the Board, and therefore, can affect the market's reaction to managerial turnover.

\subsubsection{The Board's composition}

Managerial turnover constitute a source of organisational change. Thus, a change in the CEO position entails an important degree of uncertainty for all the members in the managerial team, and in general, for all the Board's directors. The intensity of the risk perceived by the directors will depend partially on their insider or outsider origin.

The appointment of outsider managers hinders the insider manager's professional career. Firstly, a new outsider's appointment implies the loss of a job opportunity for the insider managers. Secondly, the outsiders generate prospects of organisational change that threatens the insider's jobs. A new outsider manager can consider insider managers unsuitable for undertaking important management changes because of organisational inertia and for their responsibility in past managerial actions that prevent them to correct past decisions. In that case, the outsider will probably promote changes in the managerial staff, bringing even with him members of his/her old managerial team, to help with the task of reorganising the company.

The appointment of an outsider can therefore generate an intense turnover in the managerial team being a clear hazard for the insider's professional career. According to that, Helmich and Brown (1972), Boeker (1992) and Kesner and Dalton (1994) observed more personnel turnover in the managerial second tier when the top executive is substituted by an outsider than when the substitute is an insider.

Managers, and in general all the insiders of the Board, have therefore particular interests to defend in any managerial succession process. The defence of the insider's professional interests imply their preference for insider successors. According to this, Borockhovich et al. (1996) found evidences of a negative influence of the insiders of the Board on the probability of an outsider top manager appointment. This restriction imposed by the insiders to the successor's origin can harm the shareholders' interests leading to a sub optimal CEO selection. This conflict of interests between the insiders of the Board and the shareholders becomes especially severe in disciplinary managerial turnover decisions, where a drastic organisational change is necessary.

Given that managerial succession is a source of conflicts between the insiders of the Board and the share- 
holders, if the Board of Directors is dominated by insiders, any managerial succession process will probably tend to serve to the manager's interests instead of the shareholders'. The alleviation of this agency conflict requires that the shareholders' interests are sufficiently represented in a Board of directors that is not dominated by the managers. Therefore, as noted by Fama and Jensen (1983), it is necessary to include outside independent Board Directors to guarantee the representation of the shareholders' interests in any decision that, as in the case of managerial succession, generates an agency conflict between the managers and the shareholders. Therefore, the shareholders would react more favourably to any managerial turnover decision taken by a board of directors in which the owner's interests are conveniently represented by outside directors. Consequently, we propose the following hypothesis about the control activity by Board's outsiders.

Outsiders' control Hypothesis: The proportion of outside Board Directors have a positive influence on the market's reaction to managerial turnover.

\subsubsection{Managerial stock ownership}

The managerial stock ownership generates alignment and entrenchment effects that affects managerial incentives to act in the shareholders' interest. On the one hand, in the case of a single manager-owner there are no agency problems as the manager experiments directly all the negative effects of her/his non value maximising actions (Jensen and Meckling, 1976). According to that, the negative effects of managerial opportunistic behaviour on her/his own wealth invested in the company, contributes to the alignment of managerial and shareholders' interests. Thus, managerial stock ownership incentives value enhancing activities in the firm.

Several studies corroborate the existence of an alignment effect linked to the managerial stock ownership. In this sense, Hanson and Song (2000) reported a positive relationship between the shareholders' gains from divestitures and managerial stock ownership. The study of abnormal stock market returns resulting from company mergers in the US market done by Lewellen et al. (1985) ${ }^{\mathrm{i}}$ suggests also the existence of an incentive effect linked to managerial stock ownership. This alignment of interests is confirmed by Buchhotlz and Ribbens (1994) who show the existence of a negative relationship between managerial stock ownership and the intensity of managerial resistance to takeover attempts. In this way, managerial stock ownership protects shareholders from the losses coming from managerial resistance to takeovers ${ }^{\text {ii }}$. Similar alignment effects are confirmed by Curcio (1994), who found in the UK market the existence of a positive relationship between managerial stock ownership and productivity growth.

Considering this alignment effect, any managerial succession decision will be aimed to create value for the shareholders when the insiders of the Board have a significant ownership stake in the firm. Therefore, managerial stock ownership should have a positive effect of market's reaction to managerial succession.

However, managerial stock ownership could have the opposite effects if it is high enough to insulate managers from any internal or external control. If the amount of vote rights controlled by the managerial team is large enough, the managers could indulge in opportunistic behaviour without being disciplined by the markets or the rest of the shareholders.

Several studies corroborate the existence of an entrenchment effect liked to managerial stock ownership. Denis et al. (1997) found in the US market a negative influence of the managerial stock ownership on the disciplinary role of the Board of directors. According to that resistance of the managers to the Board's control, Salancik and Pfeffer (1980) observed a positive relationship between managerial stock ownership and manager's tenure.

If there is an entrenchment effect linked to managerial stock ownership, managerial turnover decisions taken by a Board dominated by entrenched managers could easily serve to their private interests. In this case, the shareholders will be reluctant about managerial succession processes. Therefore, the manager's stock stake could reasonably have a negative influence on the market's reaction to a managerial succession event.

Taking into account the double and opposite influence of managerial stock ownership on the market's reaction to managerial succession two different hypothesis are posed: 
- $\quad$ Alignment Hypothesis: Managerial stock ownership has a positive influence on market's reaction to managerial turnover.

- $\quad$ Entrenchment Hypothesis: Managerial stock ownership has a negative influence on market's reaction to managerial turnover.

\subsubsection{The large shareholders' monitoring activity}

Performing a monitoring activity by small shareholders is economically inefficient. Monitoring shareholders incur in direct monitoring costs, but receive only benefits from this activity in proportion to their shares stake. According to that, direct monitoring costs are higher than the direct profits received by the small shareholder. Only the large shareholders are able to make a profit from managerial monitoring activities. Moreover, the large shareholders present important incentives to control managerial actions, as they bear a high proportion of the negative consequences of non value maximising actions. Thus, the presence on large shareholders tend to increase the intensity of direct supervision on managerial actions. (Shleifer and Vishny, 1986).

Different authors have corroborated the supervisory activity performed by large shareholders. Franks et al. (1997), Kaplan and Minton (1994) and Kang and Shivdasany, (1995) confirm the positive influence of large shareholders on managerial turnover in underperforming firms. In the same way, there are evidences of a higher moderation in managerial remuneration in presence of large shareholders (Dyl, 1988; Hambrick and Finkelstein, 1995).

The presence of large shareholders supervising managerial actions motivate them to act in the interest of the shareholders. Therefore, in the event of a managerial substitution, large shareholders induce the selection of a successor with the best prospects of value creation for shareholders. According to that, we propose the following hypothesis about the supervisory role of large shareholders.

Large shareholders supervision: The large shareholdings have a positive influence on market reactions to managerial turnover.

\subsection{The relevance of successor's origin}

The previous organisational membership of the successor appointed have an impact on the expected managerial behaviour, and therefore, is likely to affect the shareholders' expectations respecting the future of the company. Successor's outside/inside origin conveys information about the propensity of the new manager to implement changes in the strategies of the company. The insiders' responsibility in past managerial decisions in the firm (Wiersema, 1992) and the similarity in problem identification and problem solving in a cohesive group of insiders (Pfeffer, 1985) make inside successors less likely to induce an intense reorientation in the firm's strategies. On the contrary, outside successors are seen as portents of major changes in the company (Guest, 1962; Helmich and Brown, 1972). According to that, different authors have found evidences of more intense organisational changes when the successor is an outsider than in the case when is an insider (Boeker, 1992; Helmich, 1974; Helmich and Brown, 1972; Kesner and Dalton, 1994; Wiersema, 1992).

The change in strategic direction is likely to be welcome by the shareholders when the company presuccession performance has been poor. However, when the firm's performance has been good, the shareholders are going to be suspicious about any major organisational change. According to that, the expected market reaction to managerial succession depends both in the origin of the successor and in the perceived need for organisational change. Outsider successors are presumably most welcome in underperforming companies and insiders are preferred in good performing companies, generating in both cases positive market reactions. On the other hand outsiders can result excessively disruptive when the company has a good performance and the stability arising from a inside successor is not going to be welcome in underperforming companies. In both kinds of changes we expect a negative reaction from the market.

Therefore we propose the following hypothesis: 
- $\quad$ Origin's relevance hypothesis: Outsider successors in underperforming companies and insider successors in high performing companies are going to generate positive market reactions, while outsider successors in high performing firms and insider successors in underperforming companies are likely to generate negative market reactions.

\section{Methodology And Variables}

The main aim of our study is to analyze the market's reaction to managerial turnover events and the determinants of this reaction. We measure the market reaction by calculating the firm's daily abnormal return around the event's day. The abnormal return measures the effect of new information released to the market by the turnover announcement on the investors expectations about the future cash flows generated by the firm. In order to analyze the determinants of the observed abnormal returns several OLS linear regression models are estimated, where the dependant variable is the cumulative abnormal returns around the announcement of managerial turnover (CAR01). We accumulate abnormal returns around the event's day, using the interval $(0,+1)$ as our dependent variable.

To analyze the effect of preturnover performance on market's reaction to managerial turnover, we include in the model the firm's market performance in the 365-day period ending 21 days before the date of the turnover announcement (PERF). This firm's market performance measure has been also adjusted by the Madrid Stock Exchange Index return for the same period (ADJPERF). If, as discussed previously, managerial turnover is a way to bring about organizational change, the reaction to this event is going to be negatively correlated to firm's previous performance.

To test the outsider's control hypothesis we include the percentage of Board outsiders (POUT). We consider outsiders all those Directors that are not present managers of the company and have not been in the past and that have not either family ties with any present or past manager of the company. If according to our hypothesis, the outsiders provide the Board with independence and objectivity, necessary to keep the Board's decisions in line with shareholders' interests, we expect a positive relationship between this variable and the dependent variable (CAR01). Following Weisbach (1988) we capture also the effect of the Board composition using a set of dummy variables that represent an outsider dominated Board (DOUT) a balanced Board (MIX) and an insider dominated Board (DINS), being these variables defined as follows:

\begin{tabular}{|l|l|}
\hline DOUT $=1$ & If the proportion of outside Directors is $60 \%$ or higher \\
\hline DOUT $=0$ & Otherwise \\
\hline MIX $=1$ & If the proportion of outside Directors is the range of $40 \%$ to $60 \%$ \\
\hline MIX $=0$ & Otherwise \\
\hline DINS $=1$ & If the proportion of outside directors is under $40 \%$ \\
\hline DINS $=0$ & Otherwise \\
\hline
\end{tabular}

Considering the supervisory and control activity performed by the Board's outsiders we expect that market reactions will be the most positive when managerial turnover decisions are taken by an outsider dominated Board of Directors. We expect therefore a positive coefficient for the DOUT variable. In order to analyze the possible existence of alignment and entrenchment effects linked to managerial stock ownership, the accumulated stock ownership of all Board insiders (INOWN) is included in the regression model. If the market considers that managerial stock ownership incentives value enhancing actions, we expect to obtain a positive relationship between managerial stock ownership (INOWN) and the dependent variable (CAR01). On the other hand, if the market considers that managerial stock ownership is a mean to isolate managers from external control, we expect to obtain a negative relationship between managerial stock ownership (INOWN) and the market's reaction to managerial turnover (CAR01).

To test if the large shareholders supervise managerial actions we include in the model the joint stock ownership of the three non executive largest shareholders (LARGE3). The large shareholders will take steps to avoid any wealth loss due to an inadequate managerial substitution decision. Therefore, we expect to obtain a positive relationship between the large shareholders' stock ownership (LARGE3) and the market's reaction to managerial substitution (CAR01). To analyze the possible differences in large shareholders' behavior depending on their nature we include in the model the joint stock ownership of financial institutions (BANKS), the joint stock ownership of non financial companies (NOFIN) and the joint stock ownership of institutional shareholders (FUNDS). If these large 
shareholders play a supervisory role, we expect a positive relationship between these variables and the market's reaction to managerial turnover (CAR01).

The joint effect of the successor's origin and the perceived need of organizational change on the market's reaction to managerial turnover are tested by including in the model a set of dummy variables that identify several possible turnover processes. These variables are defined as follows:

\begin{tabular}{|l|l|}
\hline COUPLED $=1$ & $\begin{array}{l}\text { If the successor's origin matches the need for organizational change in the company. Insider origin/good } \\
\text { preturnover performance and outsider origin/poor preturnover performance. }\end{array}$ \\
\hline COUPLED $=0$ & $\begin{array}{l}\text { If the successor's origin does not match the need for organizational change in the company. } \\
\text { Outsider origin/good preturnover performance and insider origin/poor preturnover performance. }\end{array}$ \\
\hline
\end{tabular}

\begin{tabular}{|l|l|}
\hline OUT/POOR & $\begin{array}{l}\text { Equals 1 if the successor is an outsider } \\
\text { previi and the company underperformed the market in the year period }\end{array}$ \\
\hline OUT/GOOD & $\begin{array}{l}\text { Equals 1 if the successor is an outsider and the company outperformed the market in the year period previous } \\
\text { to managerial turnover and zero otherwise }\end{array}$ \\
\hline INS/POOR & $\begin{array}{l}\text { Equals 1 if the successor is an insider and the company underperformed the market in the year period previous } \\
\text { to managerial turnover and zero otherwise }\end{array}$ \\
\hline INS/GOOD & $\begin{array}{l}\text { Equals 1 if the successor is an insider and the company outperformed the market in the year period previous to } \\
\text { managerial turnover and zero otherwise }\end{array}$ \\
\hline
\end{tabular}

We expect that the market reaction is going to be higher when there is a good match between the successors origin and the perceived need for organizational change. That is, an outsider successor when low presucession performance claims for organizational changes (OUT/POOR) and an insider successor when good presucession performance claims for continuity (INS/GOOD). Thus, we expect to obtain positive coefficients for these two variables and for the variable (COUPLED) that represents this two situations when taking the value of one. In the other cases (OUT/GOOD) and (INS/POOR) we expect the market to react negatively, as the propensity of the successor to undertake changes in the company does not match the need for organizational change. According to this, we expect to record a negative relationship between these variables and the dependent variable (CAR01).

The regression model finally estimated is as follows:

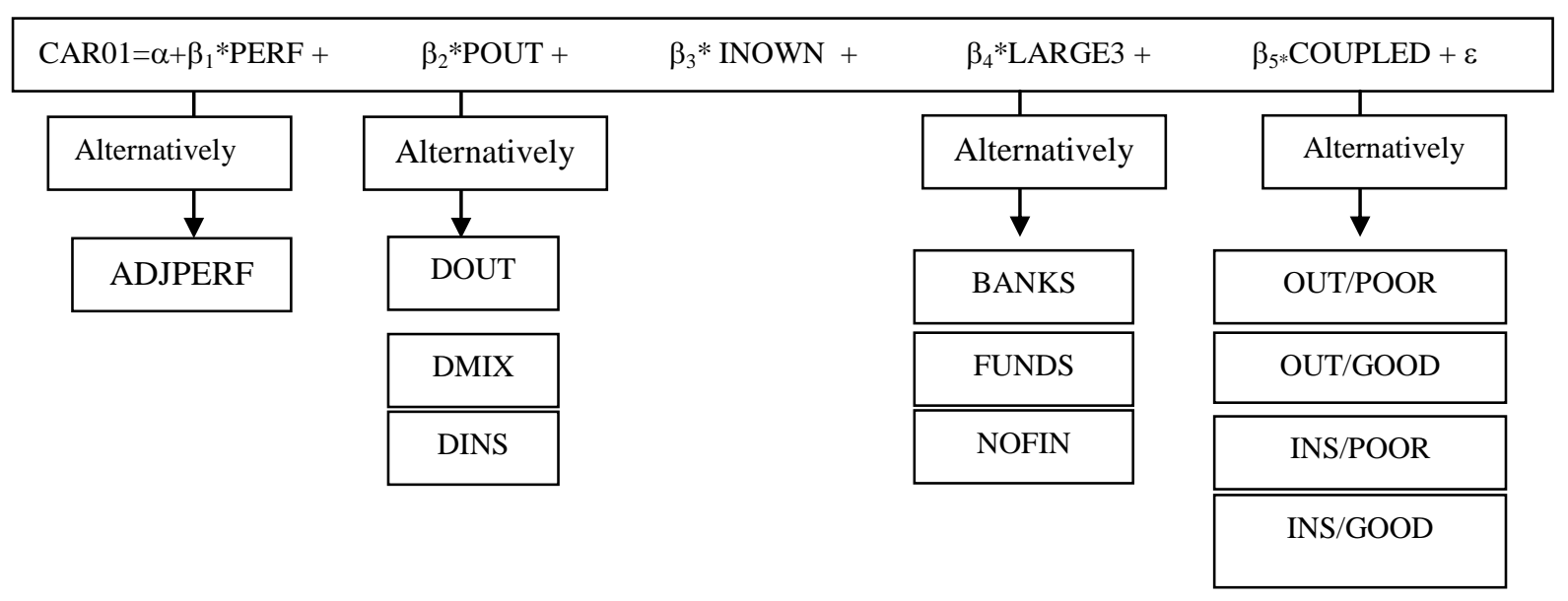

\section{Sample And Database}

The initial sample for our study is formed by 234 president and CEO changes that occur in the interval 
1990-97 for a group of 155 companies listed on the Madrid Stock Exchange. All the managerial turnover announcements have been collected by revising the Economic press. For a turnover decision to be included in the sample we have to be able to identify an announcement date in one of the main national economic journals, i.e. Expansión, Gaceta de los Negocios or Cinco Días. Also, we restrict our sample to those companies for which no contaminating announcement was found around the managerial turnover announcement dates. We additionally required that stock ownership data, Board's and managerial team composition data were available. With this selection criteria the final database consists of 106 top manager turnover announcements. Table 1 shows the chronological distribution of managerial turnover announcements.

Table 1: Chronological distribution of top manager's turnover announcements.

\begin{tabular}{|ccccccccc|}
\hline $\mathbf{1 9 9 0}$ & $\mathbf{1 9 9 1}$ & $\mathbf{1 9 9 2}$ & $\mathbf{1 9 9 3}$ & $\mathbf{1 9 9 4}$ & $\mathbf{1 9 9 5}$ & $\mathbf{1 9 9 6}$ & $\mathbf{1 9 9 7}$ & Total \\
\hline 6 & 12 & 20 & 24 & 21 & 11 & 6 & 6 & 106 \\
\hline
\end{tabular}

As it can be seen the main part of our sample is concentrated in the 1992-94 interval, which were years characterized by a turbulent economic environment and a general economic recession in the Spanish economy. Apparently, the economic recession triggers the managerial turnover decision as a mean to correct the firm's low performance.

To compute the wealth effects associated to managerial turnover announcements, market model parameters are estimated for a period from 200 to 20 days before the announcement date. To test the statistical significance of our results we use the parametric test described by Dodd and Warner (1983). The announcement date is the first day a mention of the managerial turnover appears in the press. The stock prices, dividends and subscription rights necessary to estimate market model parameters and preturnover performance have been extracted from the Daily Bulletin of the Madrid Stock Exchange.

The composition of the board of directors has been extracted from the registers of the Spanish Stock Exchange Commission. We have compared this data with the composition of the Board showed at the firm's annual report whenever we had this document. The composition of the managerial team, necessary to classify the directors in the category of insiders and outsiders have been consulted in different firm's and manager's directories, (Nueva Empresa, Dun's and Dicodi) ${ }^{\text {iv }}$. Finally, the various stock ownership variables used in this study have been extracted from the registers of the Spanish Stock Exchange Commission. The descriptive statistics for all the variables used in the empirical contrasts are shown in table 2.

The mean abnormal return (CAR01) resulting from a managerial turnover announcement is $0.70 \%$. This suggests that the market assumes that the average succession decision is positive for the shareholders' wealth. The preturnover performance in the year before managerial turnover is $4.70 \%$, but when adjusted by the market performance it results $-1.01 \%$ which means that the mean company that suffers a managerial succession process underperformed the market in the year previous to the managerial change. This negative adjusted preturnover performance could indicate the disciplinary role of managerial turnover in the total sample ${ }^{\mathrm{v}}$.

The mean proportion of outside Board directors is $65.64 \%$ which is similar to the $60.09 \%$ mean value registered in the US market by Barnhart et al. (1994). The ownership structure clearly differs from those recorded in studies conducted in Anglo-Saxon economies. The mean stock ownership of the three largest shareholders in our sample is $51.76 \%$ while the mean stock ownership by the five and twenty largest shareholders recorded by Demsetz and Lehn (1985) for the US market is only $24.81 \%$ and $37.66 \%$ respectively. This clearly reveals the existence of a much higher stock ownership concentration in the Spanish market. The stock ownership of managers is much lower in our Spanish sample compared to Anglo-Saxon economies. We have recorded a mean $1.12 \%$ stock ownership compared to 11,7\% recorded by Denis et al. (1997) in the US market and mean values in the UK market that ranged from 13,34\% to $11,47 \%$ (Short and Keasey, 1998). This ownership pattern points to a continental-type corporate governance system based on internal control provided by a high stock ownership concentration. 
Table 2: Descriptive statistics

\begin{tabular}{|lccccc|}
\hline & Mean & Std.Dev. & Minimum & Maximum & Cases \\
\hline CAR01 & $0.70 \%$ & $3.24 \%$ & $-9.00 \%$ & $13.41 \%$ & 106 \\
PERF & $4.70 \%$ & $64.96 \%$ & $-81.03 \%$ & $392.08 \%$ & 106 \\
ADJPERF & $-1.01 \%$ & $58.12 \%$ & $-78.72 \%$ & $372.13 \%$ & 106 \\
POUT & $65.64 \%$ & $20.47 \%$ & $0.00 \%$ & $100.00 \%$ & 106 \\
DOUT & 0.7075 & 0.4571 & 0.0000 & 1.0000 & 106 \\
DMIX & 0.1981 & 0.4005 & 0.0000 & 1.0000 & 106 \\
DINS & 0.0943 & 0.2937 & 0.0000 & 1.0000 & 106 \\
PINS & $1.12 \%$ & $3.66 \%$ & $0.00 \%$ & $24.97 \%$ & 106 \\
LARGE3 & $51.76 \%$ & $31.57 \%$ & $0.09 \%$ & $92.78 \%$ & 106 \\
BANK & $10.04 \%$ & $17.79 \%$ & $0.00 \%$ & $85.01 \%$ & 106 \\
FUND & $1.44 \%$ & $9.26 \%$ & $0.00 \%$ & $90.08 \%$ & 106 \\
NOFIN & $38.59 \%$ & $32.36 \%$ & $0.00 \%$ & $95.79 \%$ & 106 \\
COUPLED & 0.4811 & 0.5020 & 0.0000 & 1.0000 & 106 \\
OUT/POOR & 0.2830 & 0.4526 & 0.0000 & 1.0000 & 106 \\
OUT/GOOD & 0.2075 & 0.4075 & 0.0000 & 1.0000 & 106 \\
INS/POOR & 0.3113 & 0.4652 & 0.0000 & 1.0000 & 106 \\
INS/GOOD & 0.1981 & 0.4005 & 0.0000 & 1.0000 & 106 \\
\hline
\end{tabular}

Regarding the type of successor, the sample is balanced, containing a $49 \%$ of outsider successors and a $51 \%$ of inside successors. If we consider presuccession performance we observe that managerial changes are prevalent in underperforming companies. Around $60 \%$ of our sample is comprised by companies that were underperforming the market while $40 \%$ correspond to firms that were outperforming the market. This points out to the disciplinary role of managerial turnover.

\section{Results}

Table 3 shows the abnormal returns around the announcement of a change in the president or CEO position. For the whole sample we observe a positive market's reaction of $0.58 \%$ in the event's day and $0.7 \%$ in the interval $(0 ;+1)$ being both statistically significant at least at the $5 \%$ level. This result supports the "common sense" theoretical approach to managerial succession, according to which, managerial turnover is an opportunity to improve the managerial team capabilities and therefore, the expected firm's outcomes.

In the sub sample composed by outside successors we observe positive and statistically significant reactions in all the considered windows around the event's day. In the sub sample of inside successors the market's reaction is not significant in any event window round the event's day. When compared to the outsiders sub sample, we observe more positive reactions in this one, evidencing that the market considers that outside succession events do affect positively the investor's cash flow expectations while an inside succession does not have any significant effect. Finally the underperforming $(A D J P E R F<0)$ and over performing sub samples $(A D J P E R F>0)$ offer results quite similar to the outsiders' and insiders' sub sample, showing statistically significant reactions when a firm is underperforming the market, but not when its performance is higher than the market's one. This suggests that a succession event results significant when there is a need to correct non value enhancing managerial actions. 
Table 3: CAR around CEO's or president's turnover announcement.

\begin{tabular}{|cc|cccc|}
\hline Interval & Total & Outsiders & Insiders & ADJPERF $<$ O & ADJPERF>0 \\
\hline $\mathbf{0}$ & $0,0058^{* *}$ & $0,0095^{*}$ & 0,0023 & $0,0048^{* *}$ & 0,0072 \\
& $(2,8041)$ & $(2,0036)$ & $(1,9635)$ & $(3,2921)$ & $(0,4178)$ \\
$(\mathbf{- 1 ; 0 )}$ & 0,0074 & $0,0164^{*}$ & $-0,0009$ & $0,0064^{*}$ & 0,0088 \\
& $(1,7983)$ & $(2,1594)$ & $(0,4172)$ & $(2,5669)$ & $(-0,2835)$ \\
$(\mathbf{0} ; \mathbf{+ 1}$ & $0,007^{*}$ & $0,0121^{*}$ & 0,0022 & $0,0088^{*}$ & 0,0043 \\
& $(2,1296)$ & $(2,04)$ & $(0,992)$ & $(2,4051)$ & $(0,4325)$ \\
$(\mathbf{- 1 ; + 1 )}$ & 0,0086 & $0,0189^{*}$ & $-0,001$ & $0,0104^{*}$ & 0,0059 \\
& $(1,5882)$ & $(2,2721)$ & $(0,017)$ & $(2,1589)$ & $(-0,1196)$ \\
\hline
\end{tabular}

*** Statistically significant at $5 \%$ and $1 \%$ level. $\mathrm{Z}$ values in parenthesis

Table 4: Determinants of market reaction to managerial turnover (Unadjusted performance)

OLS estimates. Dependent variable: (CAR01)

Preturnover unadjusted firm's market performance (PERF)

\begin{tabular}{|c|c|c|c|c|c|c|c|c|}
\hline & REG1 & REG2 & REG3 & REG4 & REG5 & REG6 & REG7 & REG8 \\
\hline PERF & $\begin{array}{l}-0,0115 \\
(0,0164)\end{array}$ & $\begin{array}{l}-0,0113 \\
(0,0172)\end{array}$ & $\begin{array}{l}-0,041 \\
(0,009)\end{array}$ & $\begin{array}{c}-0,042 \\
(0,007)\end{array}$ & $\begin{array}{l}-0,012 \\
(0,038)\end{array}$ & $\begin{array}{l}-0,011 \\
(0,056)\end{array}$ & $\begin{array}{l}-0,043 \\
(0,008)\end{array}$ & $\begin{array}{c}-0,042 \\
(0,007)\end{array}$ \\
\hline POUT & $\begin{array}{c}0,000 \\
(0,9211)\end{array}$ & $\begin{array}{c}0.000 \\
(0,9989)\end{array}$ & & & $\begin{array}{c}0,000 \\
(0,746)\end{array}$ & $\begin{array}{c}0,000 \\
(0,958)\end{array}$ & & \\
\hline DOUT & & & $\begin{array}{l}0,000 \\
(0,98)\end{array}$ & $\begin{array}{c}-0,001 \\
(0,839)\end{array}$ & & & $\begin{array}{l}-0,003 \\
(0,66)\end{array}$ & $\begin{array}{c}-0,002 \\
(0,708)\end{array}$ \\
\hline DMIX & & & $\begin{array}{c}0,01 \\
(0,371)\end{array}$ & $\begin{array}{c}0,006 \\
(0,564)\end{array}$ & & & $\begin{array}{c}0,007 \\
(0,531)\end{array}$ & $\begin{array}{c}0,004 \\
(0,689)\end{array}$ \\
\hline $\begin{array}{l}\text { PERF*DOU } \\
T\end{array}$ & & & $\begin{array}{c}0,033 \\
(0,043)\end{array}$ & $\begin{array}{c}0,034 \\
(0,032)\end{array}$ & & & $\begin{array}{c}0,034 \\
(0,039)\end{array}$ & $\begin{array}{c}0,035 \\
(0,031)\end{array}$ \\
\hline $\begin{array}{l}\text { PERF*DMI } \\
\mathrm{X}\end{array}$ & & & $\begin{array}{c}0,037 \\
(0,215)\end{array}$ & $\begin{array}{c}0,031 \\
(0,301)\end{array}$ & & & $\begin{array}{c}0,036 \\
(0,234)\end{array}$ & $\begin{array}{c}0,031 \\
(0,305)\end{array}$ \\
\hline PINS & $\begin{array}{l}-0,0016 \\
(0,0489)\end{array}$ & $\begin{array}{l}-0,0017 \\
(0,0407)\end{array}$ & $\begin{array}{c}-0,002 \\
(0,055)\end{array}$ & $\begin{array}{c}-0,002 \\
(0,052)\end{array}$ & $\begin{array}{l}-0,002 \\
(0,039)\end{array}$ & $\begin{array}{l}-0,002 \\
(0,034)\end{array}$ & $\begin{array}{l}-0,002 \\
(0,044)\end{array}$ & $\begin{array}{c}-0,002 \\
(0,044)\end{array}$ \\
\hline LARGE3 & $\begin{array}{c}0,0001 \\
(0,2071)\end{array}$ & & $\begin{array}{c}0,000 \\
(0,564)\end{array}$ & & $\begin{array}{c}0,000 \\
(0,359)\end{array}$ & & $\begin{array}{c}0,000 \\
(0,758)\end{array}$ & \\
\hline BANK & & $\begin{array}{c}0.000 \\
(0,9539)\end{array}$ & & $\begin{array}{c}0,000 \\
(0,778)\end{array}$ & & $\begin{array}{c}0,000 \\
(0,967)\end{array}$ & & $\begin{array}{c}0,000 \\
(0,842)\end{array}$ \\
\hline FUNDS & & $\begin{array}{c}0,0008 \\
(0,0124)\end{array}$ & & $\begin{array}{c}0,001 \\
(0,018)\end{array}$ & & $\begin{array}{c}0,001 \\
(0,022)\end{array}$ & & $\begin{array}{c}0,001 \\
(0,032)\end{array}$ \\
\hline NOFIN & & $\begin{array}{c}0,0001 \\
(0,4108)\end{array}$ & & $\begin{array}{c}0,000 \\
(0,621)\end{array}$ & & $\begin{array}{c}0,000 \\
(0,649)\end{array}$ & & $\begin{array}{c}0,000 \\
(0,836)\end{array}$ \\
\hline COUPLED & $\begin{array}{c}0,0078 \\
(0,1805)\end{array}$ & $\begin{array}{c}0,0096 \\
(0,0955)\end{array}$ & $\begin{array}{c}0,008 \\
(0,191)\end{array}$ & $\begin{array}{c}0,009 \\
(0,114)\end{array}$ & & & & \\
\hline OUT/POOR & & & & & $\begin{array}{c}0,014 \\
(0,057)\end{array}$ & $\begin{array}{c}0,015 \\
(0,045)\end{array}$ & $\begin{array}{c}0,014 \\
(0,059)\end{array}$ & $\begin{array}{c}0,015 \\
(0,051)\end{array}$ \\
\hline OUT/GOO & & & & & 0,008 & 0,005 & 0,011 & 0,007 \\
\hline D & & & & & $(0,4)$ & $(0,637)$ & $(0,258)$ & $(0,493)$ \\
\hline INS/POOR & & & & & $\begin{array}{c}0,005 \\
(0,558)\end{array}$ & $\begin{array}{c}0,006 \\
(0,551)\end{array}$ & $\begin{array}{c}0,007 \\
(0,414)\end{array}$ & $\begin{array}{c}0,007 \\
(0,458)\end{array}$ \\
\hline $\mathbf{F}$ & $\begin{array}{c}3.49 \\
(0,0116)\end{array}$ & $\begin{array}{c}3.24 \\
(0.0059)\end{array}$ & $\begin{array}{c}2.75 \\
(0.0125)\end{array}$ & $\begin{array}{c}2.81 \\
(0,0056)\end{array}$ & $\begin{array}{c}2.60 \\
(0,0222)\end{array}$ & $\begin{array}{c}2.59 \\
(0.0131)\end{array}$ & $\begin{array}{c}2.36 \\
(0.0185)\end{array}$ & $\begin{array}{c}2.41 \\
(0.0109)\end{array}$ \\
\hline $\mathbf{R}^{2}$ & $8.40 \%$ & $11.36 \%$ & $10.31 \%$ & $13.43 \%$ & $8.35 \%$ & $10.79 \%$ & $10.47 \%$ & $12.89 \%$ \\
\hline
\end{tabular}

$\mathrm{P}$ values in parenthesis 


\begin{tabular}{|c|c|}
\hline CAR01 & Cumulated daily abnormal in the $(0,+1)$ window \\
\hline PERF & Firm's market performance in the window $(-385,-21)$ \\
\hline POUT & Proportion of Board's outsiders \\
\hline DOUT & $=1$ if the proportion of Board's outsiders is higher than $60 \% .0$ otherwise \\
\hline DMIX & $=1$ if the proportion of Board's outsiders is between $40 \%$ and $60 \% .0$ otherwise \\
\hline INOWN & Stock ownership of the Board's insiders \\
\hline LARGE3 & Joint stock ownership of the largest three non executive shareholders. \\
\hline BANK & Joint stock ownership of financial institutions \\
\hline FUND & Joint stock ownership of institutional shareholders \\
\hline NOFIN & Joint stock ownership of non financial companies. \\
\hline COUPLED & $\begin{array}{l}=1 \text { if the successor's origin matches the need for organisational change in the company. Insider origin/good } \\
\text { pretunrover performance and outsider origin/poor preturnover performance. } 0 \text { otherwise }\end{array}$ \\
\hline OUT/POOR & $\begin{array}{l}=1 \text { if the successor is an outsider }{ }^{\mathrm{vi}} \text { and the company underperformed the market in the year period previous to } \\
\text { managerial turnover and zero otherwise }\end{array}$ \\
\hline OUT/GOOD & $\begin{array}{l}=1 \text { if the successor is an outsider and the company outperformed the market in the year period previous to } \\
\text { managerial turnover. }=0 \text { otherwise }\end{array}$ \\
\hline INS/POOR & $\begin{array}{l}=1 \text { if the successor is an insider and the company underperformed the market in the year period previous to ma- } \\
\text { nagerial turnover. }=0 \text { otherwise }\end{array}$ \\
\hline
\end{tabular}

Tables 4 and 5 display the results about the determinants of the market's reaction to managerial turnover events. We observe a negative and statistically significant relationship between the firm's preturnover performance and the market's reaction to a managerial turnover event. This result supports our first hypothesis and suggests that that the managerial turnover decisions are most welcome when the firm's poor performance calls for major organizational changes. The negative relationship between preturnover performance and the abnormal returns around the managerial turnover event implies that the market considers managerial turnover as a mechanism of organizational adaptation (Pfeffer and Salancik, 1978). Managerial succession results especially valuable when there is a lack of adaptation of the firm to its environment that causes a firm's poor performance.

Contrarily to what we expected according to our outsider supervision hypothesis, we have obtained negative although not statistically significant coefficients for the variable representing the proportion of Board's outsiders (POUT). In the same way, we have obtained negative ${ }^{\text {vii }}$ coefficients for the dummy variable representing an outsider's dominance of the Board of directors (DOUT). These results are contrary to our outsider's control hypothesis, and therefore we cannot say that the market is more positive about managerial succession decisions taken by a Board dominated by outsiders. In that way, the Board outsiders do not appear to protect the shareholders' interests in crucial decisions that, as in the case of managerial succession, imply a strong interest conflict between the managers and the shareholders.

However, we obtain positive and statistically significant coefficients for the interaction terms of the firm's presuccession performance and Board's composition (DOUT*PERF) and (DOUT*ADJPERF). The different sign of the coefficients obtained for preturnover performance (PERF and ADJPERF) and the interaction terms (DOUT*PERF) and (DOUT*ADJPERF) implies that, given a certain preturnover performance, the market reaction results less intense when the Board is dominated by outsiders than in the case of an insider dominated Board. This result seems to be, once again, contrary to our expectations as the supervisory role of the Boards' outsiders could suggest the existence of more intense and significant reactions in outside-dominated Boards. However, we interpret this finding in a different way, If an outsider dominated Board is considered by the market as a "good control" the market will anticipate the turnover decision when necessary. Therefore, the market reaction to managerial succession will result stronger in insider dominated Boards, where the market does not anticipate that a necessary change is going to occur. In this way, a less intense reaction in outsider dominated Boards are coherent with a scenario in which the outsiders are playing a monitoring role and the market knows it. 
Table 5: Determinants of market reaction to managerial turnover (adjusted performance)

OLS estimates. Dependent variable: (CAR01).

Preturnover firm's market performance adjusted for de market index performance (ADJPERF).

\begin{tabular}{|c|c|c|c|c|c|c|c|c|}
\hline & REG1 & REG2 & REG3 & REG4 & REG5 & REG6 & REG7 & REG8 \\
\hline ADJPERF & $\begin{array}{l}-0,0125 \\
(0,021)\end{array}$ & $\begin{array}{c}-0,0132 \\
(0,0133)\end{array}$ & $\begin{array}{l}-0,064 \\
(0,002)\end{array}$ & $\begin{array}{l}-0,065 \\
(0,002)\end{array}$ & $\begin{array}{l}-0,012 \\
(0,056)\end{array}$ & $\begin{array}{c}-0,012 \\
(0,047)\end{array}$ & $\begin{array}{l}-0,065 \\
(0,003)\end{array}$ & $\begin{array}{c}-0,065 \\
(0,002)\end{array}$ \\
\hline POUT & $\begin{array}{c}0.0000 \\
(0,9425)\end{array}$ & $\begin{array}{c}0.0000 \\
(0,9583)\end{array}$ & & & $\begin{array}{l}0.000 \\
(0,82)\end{array}$ & $\begin{array}{c}0.000 \\
(0,984)\end{array}$ & & \\
\hline DOUT & & & $\begin{array}{c}0,001 \\
(0,858)\end{array}$ & $\begin{array}{c}0.000 \\
(0,961)\end{array}$ & & & $\begin{array}{l}-0,001 \\
(0,876)\end{array}$ & $\begin{array}{c}-0,001 \\
(0,863)\end{array}$ \\
\hline DMIX & & & $\begin{array}{l}0,017 \\
(0,16)\end{array}$ & $\begin{array}{c}0,006 \\
(0,601)\end{array}$ & & & $\begin{array}{c}0,013 \\
(0,274)\end{array}$ & $\begin{array}{c}0,004 \\
(0,768)\end{array}$ \\
\hline ADJPERF*DOUT & & & $\begin{array}{c}0,055 \\
(0,011)\end{array}$ & $\begin{array}{c}0,056 \\
(0,008)\end{array}$ & & & $\begin{array}{c}0,055 \\
(0,011)\end{array}$ & $\begin{array}{c}0,056 \\
(0,008)\end{array}$ \\
\hline ADJPERF*DMIX & & & $\begin{array}{c}0,082 \\
(0,033)\end{array}$ & $\begin{array}{c}0,048 \\
(0,236)\end{array}$ & & & $\begin{array}{c}0,077 \\
(0,051)\end{array}$ & $\begin{array}{c}0,044 \\
(0,286)\end{array}$ \\
\hline PINS & $\begin{array}{l}-0,0017 \\
(0,0408)\end{array}$ & $\begin{array}{l}-0,0017 \\
(0,0326)\end{array}$ & $\begin{array}{l}-0,002 \\
(0,012)\end{array}$ & $\begin{array}{c}-0,002 \\
(0,012)\end{array}$ & $\begin{array}{l}-0,002 \\
(0,032)\end{array}$ & $\begin{array}{c}-0,002 \\
(0,027)\end{array}$ & $\begin{array}{c}-0,002 \\
(0,009)\end{array}$ & $\begin{array}{r}-0,002 \\
(0,01)\end{array}$ \\
\hline LARGE3 & $\begin{array}{c}0,0001 \\
(0,2506)\end{array}$ & & $\begin{array}{c}0.000 \\
(0,742)\end{array}$ & & $\begin{array}{c}0.000 \\
(0,402)\end{array}$ & & $\begin{array}{c}0.000 \\
(0,921)\end{array}$ & \\
\hline BANK & & $\begin{array}{c}0.0000 \\
(0,9964)\end{array}$ & & $\begin{array}{c}0.000 \\
(0,847)\end{array}$ & & $\begin{array}{c}0.000 \\
(0,998)\end{array}$ & & $\begin{array}{c}0.000 \\
(0,937)\end{array}$ \\
\hline FUNDS & & $\begin{array}{c}0,0009 \\
(0,0081)\end{array}$ & & $\begin{array}{c}0,001 \\
(0,019)\end{array}$ & & $\begin{array}{c}0,001 \\
(0,014)\end{array}$ & & $\begin{array}{c}0,001 \\
(0,027)\end{array}$ \\
\hline NOFIN & & $\begin{array}{c}0,0001 \\
(0,5081)\end{array}$ & & $\begin{array}{c}0.000 \\
(0,854)\end{array}$ & & $\begin{array}{c}0.000 \\
(0,739)\end{array}$ & & $\begin{array}{c}0.000 \\
(0,928)\end{array}$ \\
\hline COUPLED & $\begin{array}{l}0,0074 \\
(0,2073)\end{array}$ & $\begin{array}{c}0,0092 \\
(0,1088)\end{array}$ & $\begin{array}{c}0,007 \\
(0,188)\end{array}$ & $\begin{array}{c}0,009 \\
(0,123)\end{array}$ & & & & \\
\hline OUT/POOR & & & & & $\begin{array}{c}0,014 \\
(0,073)\end{array}$ & $\begin{array}{c}0,014 \\
(0,056)\end{array}$ & $\begin{array}{c}0,013 \\
(0,074)\end{array}$ & $\begin{array}{c}0,014 \\
(0,062)\end{array}$ \\
\hline OUT/GOOD & & & & & $\begin{array}{c}0,006 \\
(0,492)\end{array}$ & $\begin{array}{c}0,004 \\
(0,688)\end{array}$ & $\begin{array}{c}0,009 \\
(0,372)\end{array}$ & $\begin{array}{c}0,007 \\
(0,458)\end{array}$ \\
\hline INS/POOR & & & & & $\begin{array}{c}0,004 \\
(0,656)\end{array}$ & $\begin{array}{c}0,005 \\
(0,583)\end{array}$ & $\begin{array}{c}0,006 \\
(0,468)\end{array}$ & $\begin{array}{c}0,007 \\
(0,412)\end{array}$ \\
\hline $\mathbf{F}$ & $\begin{array}{c}3.29 \\
(0.0141)\end{array}$ & $\begin{array}{c}3.33 \\
(0.0049)\end{array}$ & $\begin{array}{c}3.23 \\
(0.0040)\end{array}$ & $\begin{array}{c}3.22 \\
(0.0018)\end{array}$ & $\begin{array}{c}2,47 \\
(0,0285)\end{array}$ & $\begin{array}{c}2.63 \\
(0.0118)\end{array}$ & $\begin{array}{c}2.68 \\
(0.0080)\end{array}$ & $\begin{array}{c}2.73 \\
(0.0042)\end{array}$ \\
\hline $\mathbf{R}^{2}$ & $8.01 \%$ & $11,76 \%$ & $12.93 \%$ & $15.99 \%$ & $7.76 \%$ & $11.05 \%$ & $12.59 \%$ & $15.33 \%$ \\
\hline
\end{tabular}

$\mathrm{P}$ values in parenthesis

\begin{tabular}{|c|c|}
\hline CAR01 & Cumulated daily abnormal in the $(0,+1)$ window \\
\hline ADJPERF & Firm's market performance in the window $(-385,-21)$ adjusted for the market's index performance \\
\hline POUT & Proportion of Board's outsiders \\
\hline DOUT & $=1$ if the proportion of Board's outsiders is higher than $60 \% .0$ otherwise \\
\hline DMIX & $=1$ if the proportion of Board's outsiders is between $40 \%$ and $60 \% .0$ otherwise \\
\hline INOWN & Stock ownership of the Board's insiders \\
\hline LARGE3 & Joint stock ownership of the largest three non executive shareholders. \\
\hline BANK & Joint stock ownership of financial institutions \\
\hline FUND & Joint stock ownership of institutional shareholders \\
\hline NOFIN & Joint stock ownership of non financial companies. \\
\hline COUPLED & $\begin{array}{l}=1 \text { if the successor's origin matches the need for organisational change in the company. Insider origin/good pretunrover per- } \\
\text { formance and outsider origin/poor preturnover performance. } 0 \text { otherwise }\end{array}$ \\
\hline OUT/POOR & $\begin{array}{l}=1 \text { if the successor is an outsider }{ }^{\text {viii }} \text { and the company underperformed the market in the year period previous to managerial } \\
\text { turnover and zero otherwise }\end{array}$ \\
\hline OUT/GOOD & $\begin{array}{l}=1 \text { if the successor is an outsider and the company outperformed the market in the year period previous to managerial turno- } \\
\text { ver. }=0 \text { otherwise }\end{array}$ \\
\hline INS/POOR & $\begin{array}{l}=1 \text { if the successor is an insider and the company underperformed the market in the year period previous to managerial turno- } \\
\text { ver. }=0 \text { otherwise }\end{array}$ \\
\hline
\end{tabular}


We have obtained negative and statistically significant coefficients in all regressions for the insider's stock ownership (INOWN). This result support our entrenchment hypothesis, according to which, managerial stock ownership isolates the managers from external controls, and therefore, provides the managerial team with discretion to incur in non value enhancing actions. In any managerial succession process, when the managerial team controls a significant amount of votes, they may impose their own interests regarding their professional careers, instead of promoting the most suitable candidate for the vacant, independently of her/his origin. Thus, the higher the insider's stock ownership, the less favorable investors are about managerial succession decisions.

Regarding the monitoring role of the large shareholders, we have obtained positive $\mathrm{e}^{\mathrm{ix}}$, but not statistically significant coefficients for our ownership concentration variable (LARGE3) ${ }^{\mathrm{x}}$. This result does not support our large shareholders' supervision hypothesis. However, when the nature of the large shareholders is considered, we obtain a positive and statistically significant relationship between the stock ownership of the institutional investors and the market's reaction to managerial turnover. This result suggests that the market is sensitive to the possible existence of particular interests of large shareholders that in the case of financial institutions and non financial companies could be contrary to the general interest of the small shareholders. However, in the case of institutional investors, which represent a certain mass of small shareholders, it seems that there is not such a conflict of interests, and therefore, the market trusts their supervisory action.

Finally, in reference to the combined effect of successor's origin and preturnover performance, we have found evidences that partially support our hypothesis. We have obtained positive, but non statistically significant coefficients in all the regressions for the variable (COUPLED), that represented those managerial turnover decisions in which the successor was an outsider in a poor performing company or an insider in a good performing company. In those cases, we assumed that there was a good adaptation between the successor's propensity to promote major organizational changes and the need for these changes. We cannot affirm the existence of differences in the market reaction depending on this classification scheme of the turnover events. However, when we consider dummy variables that establish four categories depending on preturnover performance and successor's origin, we obtained positive and statistically significant coefficients for the dummy representing an outsider successor in underperforming companies. This results suggest that the impact of a succession event is more intense when the successor is expected to undertake major organizational changes, and at the same time, when poor performance calls for those changes.

\section{Conclusions}

Managerial succession constitutes a crucial event for the company. On the one hand it can generate important organizational changes that will affect the shareholders' wealth. On the other hand, it is a decision that entails important conflicts of interests between the managers and the shareholders, as the manager's professional careers can result clearly damaged by an incoming outsider, while the shareholders' interests could be best served by this kind of successor. Studying the market reactions around managerial succession events, allow us to check firstly whether changing a firm's leader has an impact on the shareholders wealth, and secondly, to analyze if the control mechanisms that form the corporate governance system, act in the shareholders' best interest in the presence of a strong interest conflict.

Our study conducted in the Spanish market and based on a sample of top executive turnover announcements in the period 1990-97 evidence the relevance of the managerial turnover decisions for the shareholders' wealth. We have observed positive and statistically significant market reactions around the managerial turnover announcement. This reactions results particularly intense in the case of an incoming outside manager and when the company preturnover performance was poor. This evidence, according to other studies in the US market, suggests that managerial turnover is an opportunity to adapt the firm's strategies to a changing environment, correcting previous managerial actions that did not create value for the shareholders.

We have obtained evidence of a negative relationship between the firm's preturnover performance and the firms market reaction to managerial turnover. This finding suggests that managerial turnover is most welcomed when there is a more intense need of changes in the firm's strategies. This, once again, reveals that managerial turnover is a valuable restructuring measure that can affect the firm's future outcomes. 
Regarding the effect of the corporate governance structure, we have obtained evidences that suggest that the Board's outsiders and the institutional investors, play a major role controlling managerial deviations from value enhancing behavior. We have obtained also evidences of the existence of entrenchment effects linked to managerial stock ownership.

Our conclusions about the Spanish governance system, mainly suggest that the shareholders' interests are effectively represented by the Board of directors and institutional investors. Therefore, this control mechanisms seem to be effective enough to overcome the agency conflicts in the Spanish context characterized by a low legal protection of the shareholders' rights and a low intensity of the external control exerted by the markets.

Finally, relating the relevance of the successor's origin, our results suggest that only outside succession under the condition of preturnover poor performance, has a significant (and positive) effect on the market's reaction to managerial turnover events. These results strengthen our event study results and suggest that managerial turnover has significant effects on the firm's future performance when the successor is an outsider and the company needs a correction of its strategies. This result agrees with the view of managerial inside succession as an event that promotes stability, and therefore, has no effects on the firm's future outcomes, while outside succession promotes a reorganization of the firm that can produce significant effects on the shareholders' wealth.

\section{References}

1. Barnhart, S.W.; Marr, M.W.; Rosenstein, S. (1994): "Firm Performance And Board Composition: Some New Evidence", Managerial And Decision Economics, Vol. 15, Pages. 329-340.

2. Boeker, W. (1992): "Power And Managerial Dismissal: Scapegoating At The Top" Administrative Science Quarterly, Vol 37, Pages. 400-421.

3. $\quad$ Borokhovich, K.; Parrino, R.; Trapani, T. (1996): "Outside Directors And Ceo Selection" Journal Of Financial And Quantitative Analysis" Vol. 31, Pages. 337-355.

4. $\quad$ Bradley, M. \& Wakeman, L. (1983): "The Wealth Effects Of Targeted Share Repurchases" Journal Of Financial Economics, Vol. 11, Pages. 183-206.

5. $\quad$ Buchholtz, A.K. \& Ribbens, B.A. (1994): "Role Of Executive Officers In Takeover Resistance: Effects Of Ceo Incentives And Individual Characteristics" Academy Of Management Journal, Vol. 37, Pages. 554-579

6. Curcio, R. (1994): "The Effect Of Managerial Ownership Of Shares And Concentration Of Voting Power" Discussion Paper No. 185, Centre For Economic Performance Lse.

7. Dann, L. \& Deangelo, H. (1983): "Standstill Agreements, Privately Negotiated Stock Repurchases And The Market For Corporate Control" Journal Of Financial Economics, Vol. Vol. 11, Pages. 275-300.

8. Dann, L. \& Deangelo, H. (1988): "Corporate Financial Policy And Corporate Control: A Study Of Defensive Adjustments In Asset An Ownership Structure" Journal Of Financial Economics, Vol. 20, Pages. 87127.

9. Demsetz, H.; Lehn, K. (1985): “The Structure Of Corporate Ownership: Causes And Consequences”, Journal Of Political Economy, Vol. 93, Pages. 1155-1177.

10. Denis, D. \& Denis, D. (1995): "Performance Changes Following Top Management Changes" Journal Of Finance, Vol. 50, Pages. 1029-1057.

11. Denis, D.; Denis, D.; Sarin, A. (1997): "Ownership Structure And Executive Turnover" Journal Of Financial Economics, Vol. 45, Pages. 193-221.

12. Dodd, P.; J. Warner, J. (1983): “On Corporate Governance: A Study Of Proxy Contests”, Journal Of Financial Economics, 11, 401-438.

13. Fama, E.; Jensen, M.C. (1983): "Separation Of Ownership And Control", Journal Of Law And Economics, Vol. 27, Pages. 301-325.

14. Gamson, W \& Scotch N. (1964): “Scapegoating In Baseball” American Journal Of Sociology, Vol. 70, Pages. 69-72.

15. Grusky, O. (1963): "Managerial Succession. And Organizational Effectiveness" American Journal Of Sociology, Vol. 69, Pages. 21-31.

16. Guest, Robert H. (1962): "Managerial Succession In Complex Organizations" American Journal Of Sociology, Vol. 68, Pages 47-54. 
17. Hanson, R.C. And Song, M.H. (2000): "Managerial Ownership, Board Structure And The Division Of Gains In Divestitures" Journal Of Corporate Finance, Vol. 6 Pages. 55-70.

18. Helmich Donald L. (1974): "Organizational Growth And Succession Patterns" Academy Of Management Journal, Vol. 17, Pages. 771-775.

19. Helmich, Donald L. And Warren B. Brown (1972): "Succession Type And Organizational Change In The Corporate Enterprise" Administrative Science Quarterly; Vol. 17; Pages. 371-381.

20. Jensen, M.C.; Meckling, W.H. (1976): "Theory Of The Firm; Managerial Behaviour, Agency Costs And Ownership Structure”, Journal Of Financial Economics, Pages. 305-360.

21. Kesner, I.F. And Dalton, D.R. (1994): “Top Management Turnover And Ceo Succession: An Investigation Of The Effects Of Turnover On Performance” Journal Of Management Studies, Vol. 31, Pages. 701-713.

22. Lewellen, W.;Loderer, C.; Rosenfeld, A. ( 1985): "Merger Decisions And Executive Stock Ownership In Acquiring Firms" Journal Of Accounting And Economics, Vol. 7, Pages 209-231.

23. Pfeffer, J. \& Salancik, G. (1978) "The External Control Of Organizations" New York, Harper And Row.

24. Pfeffer, J. (1985): "Organizational Demography: Implications For Management" California Management Review, Vol. 28, Pages. 67-71.

25. Salancick, G.R. ; Pfeffer, J. (1980): "Effects Of Ownership And Performance On Executive Tenure In Us Corporations" Academy Of Management Journal, Vol. 23, Pages 653-664.

26. Shleifer, A.; Vishny, R.W. (1986): "Large Shareholder And Corporate Control”, Journal Of Political Economy, Vol. 94, Pages. 461-488.

27. Short, H., Keasey, K., (1999): "Managerial Ownership And The Performance Of Firms: Evidence From The U. K.", Journal Of Corporate Finance 5, 79-101.

28. Tushman, M. \& Rosenkopf, L. (1996): "Executive Succession, Strategic Reorientation And Performance Growth: A Longitudinal Study In The Us Cement Industry" Management Science, Vol. 42, Pages. 939-953.

29. Weisbach, M. (1995): "Ceo Turnover And The Firm's Investment Decisions" Journal Of Financial Economics; Vol. 37; Pages. 159-188.

30. Weisbach, M.S. (1988): "Outside Directors And Ceo Turnover”, Journal Of Financial Economics, Vol.20, Pages. 431-460.

31. Wiersema, M: (1992): "Strategic Consequences Of Executive Succession Within Diversified Firms" Journal Of Management Studies, Vol. 29 Pages. 73-94.

\section{Endnotes}

\footnotetext{
${ }^{\mathrm{i}}$ These authors found a positive relationship between the market abnormal return for the shareholders of the acquirer firm and the manager's stock ownership in that firm.

${ }^{\text {ii }}$ See Dan and DeAngelo, (1988) and (1983), Bradley and Wakeman, (1983) for a detailed study of the shareholders' wealth losses caused by managerial resistance to takeover attempts.

${ }^{\text {iii }}$ We considered the successor an outsider if previously to his/her appointment as manager He/she was not an employee of the company.

${ }^{\text {iv }}$ In order not to omit in the classification of insiders those directors which abandoned their managerial job before 1990, but continued as directors after this date, we have consulted the firm's and manager's directories from 1981 to 1997.

v Only $29 \%$ of the turnover announcements in this sample were defined as "retirement" or "departing for another job"

${ }^{\text {vi }}$ We considered the successor an outsider if previously to his/her appointment as manager He/she was not an employee of the company.

${ }^{\text {vii }}$ Although the reported coefficients of (POUT) and some reported for (DOUT) are equal to zero, this happens because these coefficients that are negative, but extremely close to zero, have been rounded to the third decimal.

${ }^{\text {viii }}$ We considered the successor an outsider if previously to his/her appointment as manager He/she was not an employee of the company.

${ }^{\text {ix }}$ Although the reported coefficients for (LARGE3), (BANK) and some reported for (NOFIN) are equal to zero, this happens because these coef-

ficient that are positive but extremely close to zero, have been rounded to the third decimal.

${ }^{\mathrm{x}}$ The results were similar when we use the stock ownership of the largest or the five largest non executive shareholders.
} 
Noes 